\title{
4
}

\section{St Joseph's Native School and Orphanage: Workers at the Edge of the Town}

Sometime after 1910, a photographer recorded renovations at St Joseph's Native School and Orphanage, documenting the low buildings of the new laundry to the southeast of New Norcia's monastery. The image draws the viewer's eyes across the expanse of bare ground towards a woman dressed in a religious habit who stands with a toddler at her side between the camera and the new whitewashed walls; near her a group of children cluster around a sturdy swing. ${ }^{1}$ Similarly robust posts support four neat washing lines in the foreground. At first glance in the grainy reproduction, the swing looks more like a gallows and the washing lines suggest barbwire fences.

Such stark realities fit our picture of Aboriginal Australia, and the first impression that this is an institutional photograph is accurate. But magnifying the image brings reassurance that this is also a domestic scene. In the deep verandah the camera has captured taller figures of the older girls and young women in long skirts. Enlarged further, a washing basket comes into focus, with some tubs, buckets, fine collars and cuffs, and the copper against the wall; a young woman at the far left attends to a cockatoo on her arm; on the right another veiled figure has turned towards the window. There are two children sitting on the swing. At several points the image blurs with movement: this photograph is only partly posed.

1 New Norcia Archives (NNA) 74622P. 
There is no Sunday best: the children are in shapeless pinnies, barefoot, and no one is staying still for the occasion. The photographer intended that we would see the whole, the sweep of the scene, not scrutinise the parts. But as the magnification climbs, faces emerge in the group around the swing. Technology brings features to the woman's face: not European, not Aboriginal, perhaps reflecting Consuelo's Mexican village of Chalchicomula, but then higher resolution defines the eyeglasses that confirm her as Maria Harispe. ${ }^{2}$ The children's different gazes come into focus - serious, alert, sombre, pained, curious, squinting. And then we can go no closer. The fine-grained image breaks apart, resolves into pixels, not reality. They are not there. It is the same with every photograph, every text: so far and no further.

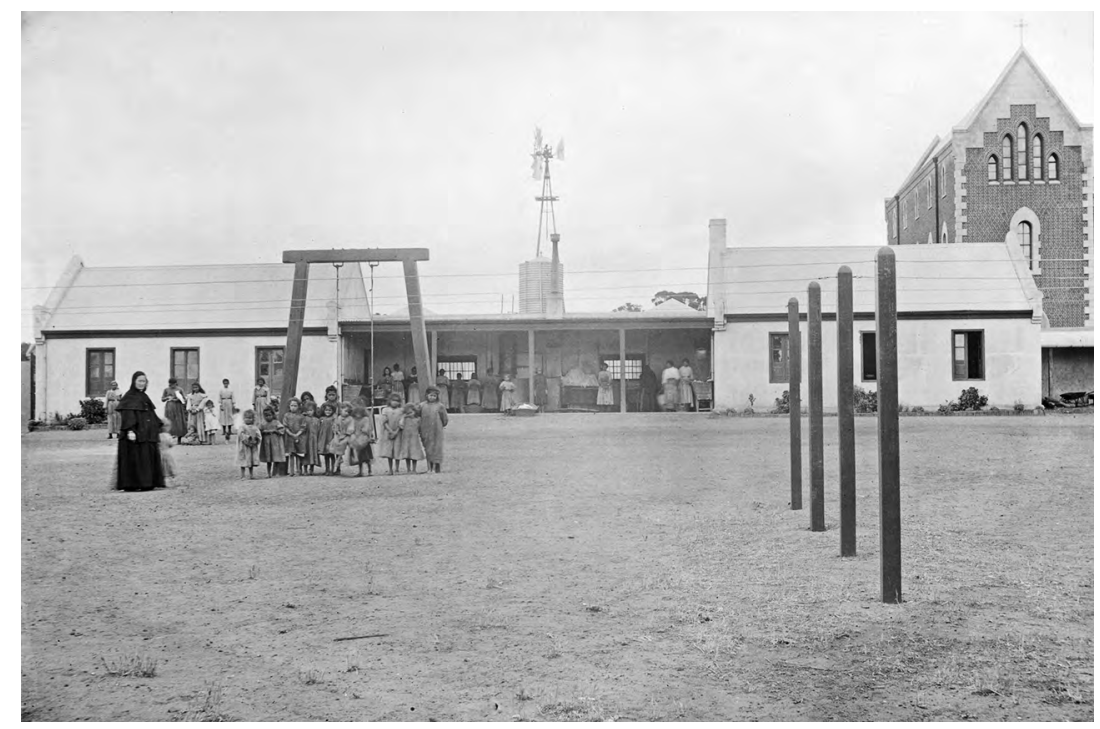

Figure 4.1: Maria and children of St Joseph's near a swing, with laundry in the background, c. 1912.

Source: NNA 74622P.

2 Maria Ana Consuelo Cristiana Dolores Batiz Abelleyra, 15 December 1877, Baptismal Register, Archive of the Parish of San Andres Chalchicomula, familysearch.org; accessed 28 July 2012. 


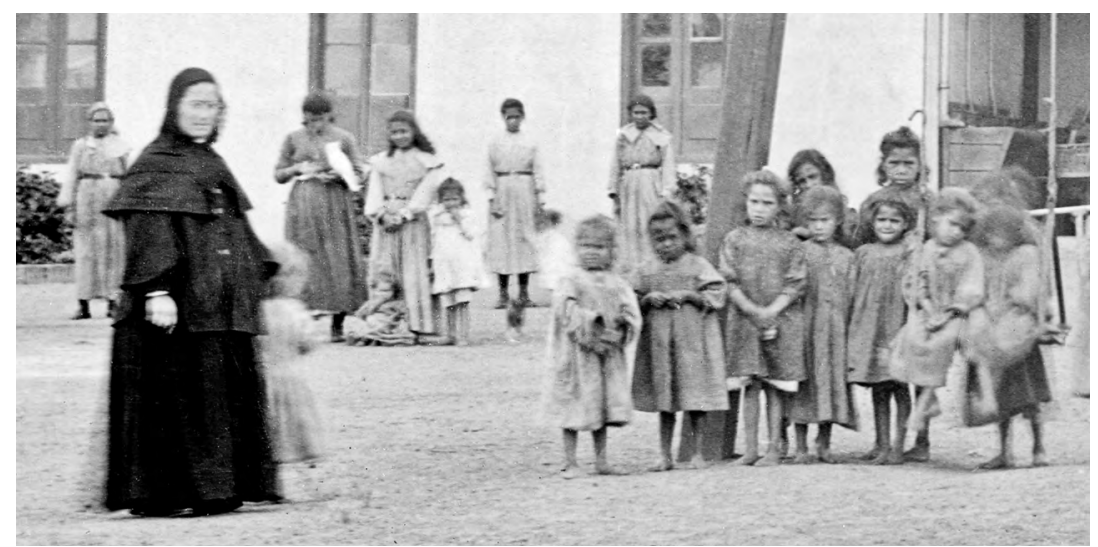

Figure 4.2: Detail of Maria and the children.

Source: NNA 74622P.

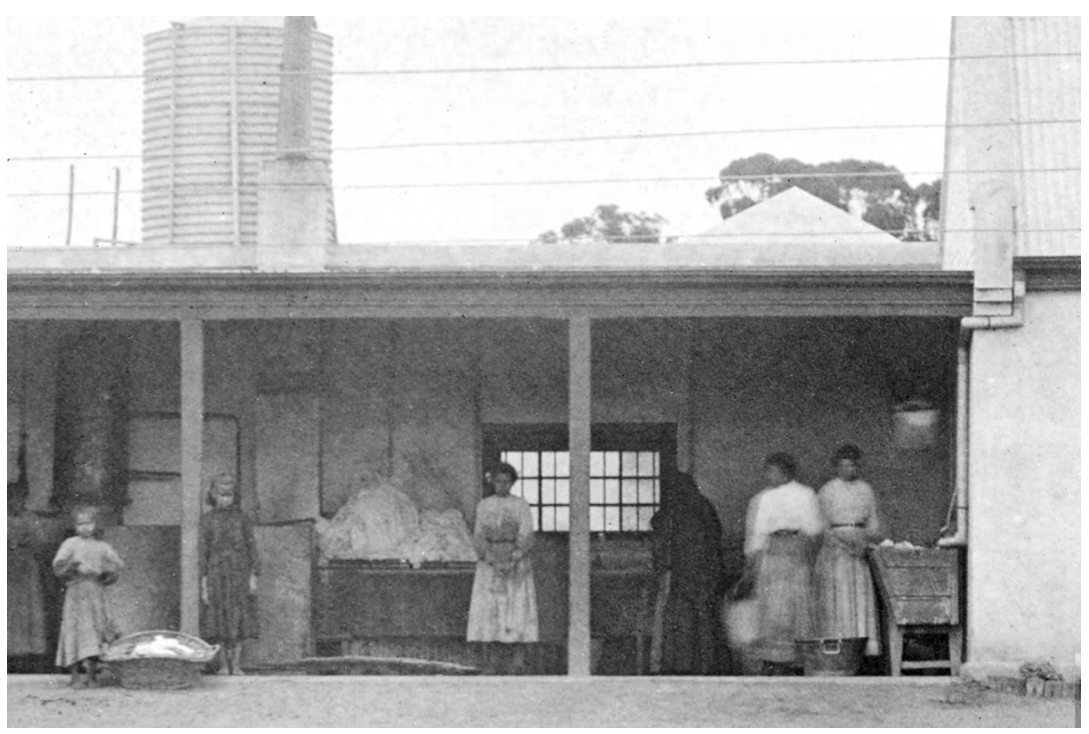

Figure 4.3: Detail of laundry work at St Joseph's, after 1910.

Source: NNA 74622P.

The site of St Joseph's itself holds fragments together across time. Just as surely as a written document, the buildings and the landscape they relate to are a text. We can trace the lives of the Benedictine sisters and the children at St Joseph's in the faint suggestions of the space just as we can catch their echo in the archival pages. In New Norcia today the swing and the clotheslines are gone, but visitors can still stand where that photographer stood and imagine the scene. The yard where Maria paced now hosts 
a barbeque when Aboriginal families gather for an annual reunion. There is a garden planted with succulents where the children once peered back into the camera, and we can still take our bearings from St Gertrude's and choose a spot within the frame. The reality of the township and its stories is reinforced by our experience of the place. Like the photographer, we are producing an image, creating a picture. We cannot see what they saw, or retrieve their experience-let's not imagine that. But we can pay attention. We are sifting and assembling fragments.

One fragment that takes on added dimensions when it is read 'in place' is the account left by G. S. Olivey who was charged by the Western Australian Government with inspecting the mission in May 1913. Olivey's report forms a spine for this chapter as we follow his progress around the site and pay attention to the physical realities of this space at the edge of the town. The picture it offers of the missionary women doing their best, 'heart and soul for their work', ${ }^{3}$ is the administrator's extension of policies directed at Aboriginal people 'for their own good'. These are the years of Consuelo's influence. This chapter ranges over earlier sources, where we glimpse her impact in the years to 1907 as well as after her return in 1912. It builds a picture of the work of the community and the assumption that domestic work would define the women. Finally, gathering together the hints of Consuelo's story, it traces the tension between a monastic vision and missionary expectations.

\section{Defining spaces: St Joseph's in a landscape}

In the renovation of 1910, distinct zones of activity had become visible at St Joseph's. We have heard of the wall and how the Aboriginal people detested it. ${ }^{4}$ But the structure that triggered the nickname Golden Gaol was not the only spatial reality to make an impact on the psyche of the town. Each of the carefully designated spaces at St Joseph's shaped experiences of the institution in patterns that endured through the decades: dormitories, laundry, kitchen and school rooms all resonated metaphorically. Overriding concerns for cleanliness, hard-working respectability and ordered seclusion

3 G. S. Olivey, Travelling Inspector, 'Report on New Norcia Mission', 7 May 1913, State Records Office of Western Australia (SROWA) S1644 cons652 1913/0213.

4 See Chapter 2. 
were coded into the physical structure. There were also signs of what $\mathrm{St}$ Joseph's was not. Stretched out from the upright edge of St Gertrude's College and overlooked by its fairy-tale tower, St Joseph's was in contrast a modest and practical building with a utilitarian windmill as its highest peak. There was a hierarchy of aspiration here: St Joseph's knew its place.

Like most visitors, the travelling inspector Olivey was struck first by New Norcia's other buildings, especially the 'imposing ... splendidly built' boarding schools, before he found the quadrangle of 'comparatively new brick buildings ... surrounding a large square' that was St Joseph's. The 'fine and airy girls' quarters' compared more than favourably with St Mary's for the Aboriginal boys, where foundations had been laid to replace the original 'dilapidated' slab hut, and it also outshone the tworoomed cottages for families. In contrast to the domestic buildings, St Joseph's had a traditional monastic layout, centred on a 'work cloister'. We know that later this central area was busy enough as a playground, but the inspector did not comment on this. When he saw it, the space for play was divided again and again by the washing lines. The inspector noted the order of buildings (dormitories on the east side faced laundry on the west, kitchen on the north had a view of a school room in the south) and that there were 29 girls. The monastery's returns show that numbers increased through this decade, having more than tripled from 11 residents (aged from one to 26 years) recorded in the care of seven sisters in 1906 to 36 residents by the end of 1917 , along with the four sisters. ${ }^{5}$

At this stage, there was no separate 'convent' for the missionary community. ${ }^{6}$ Instead, one 'retiring room' near the classroom seems to have been the only communal living space for the sisters. Neither was there a separate chapel built into the structure. There were shared devotional images, and the painting of Mary the mother of Jesus in the dormitory was an important focus for prayer of the whole institution. Outside the patterns of domestic devotion, the sisters attended regular services in the church, joined by the girls on Sundays. Through their frequent appearances in church the Benedictine sisters were connected to the wider life of the town. The regular walk around the cottages to the church at the centre of the town also marked their style of religious life as 'apostolic', not so strictly 'monastic' as other Benedictines in Europe.

5 Torres to Chief Protector, 10 September 1913, SROWA S1644 cons652 1913/0213. See also Appendix 1.

6 See Sketch Plan, St Gertrude's and St Joseph's, NNA D7:89. 


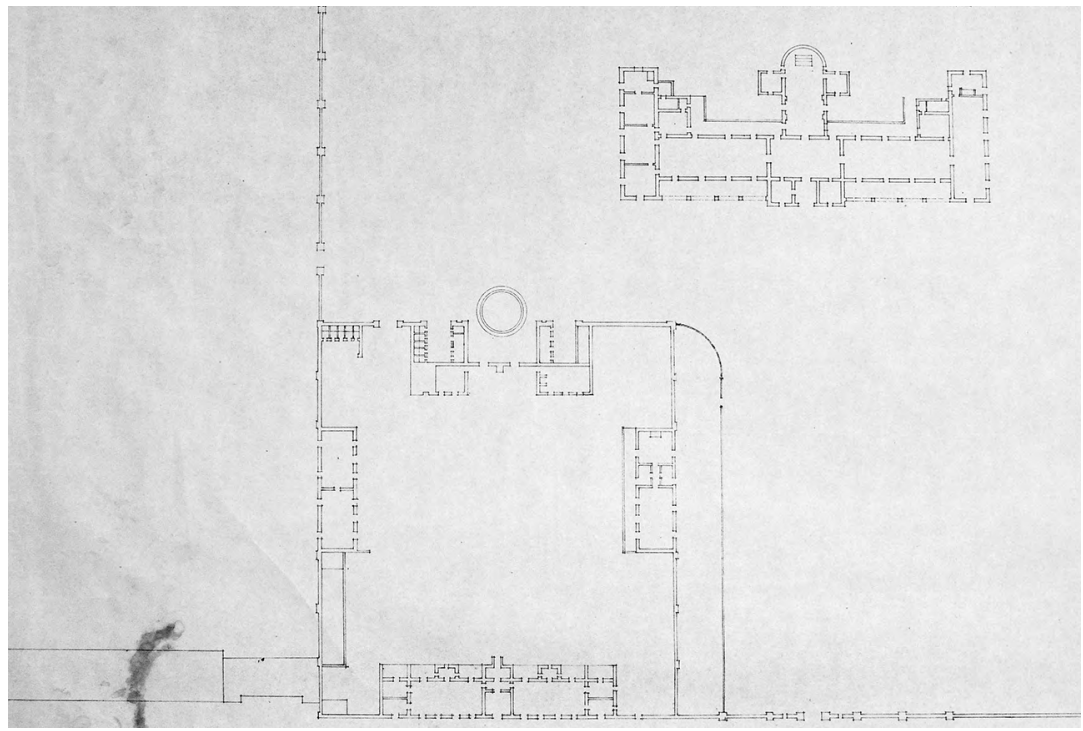

Figure 4.4: The drawings that guided the renovation at St Joseph's in 1910.

Source: NNA D7:89.

Their institution was not shuttered in the same way as traditional monastic communities of women, but nevertheless it was a distinct precinct and something of a borderland. For example, in one strange incident when rumours were flying in the middle of the First World War, word reached Consuelo at New Norcia that the Germans had invaded Geraldton, 390 kilometres north. Clearly, she was in a position to hear a rumour, true or not, and was expected to respond. Believing it to be true, she wrote an urgent letter and sent a messenger to the monastery. It is an action that shows the distance between the two institutions, on the one hand, and their interconnectedness, on the other. The report, though 'alarming to all', 7 proved to be only wild gossip. With the telegraph within their walls, the monks had access to official news, but the convent had heard the story first. Physically across the road and at the edge of the town, St Joseph's was metaphorically at a boundary linking the mission and the monastery, connecting the Benedictine and Aboriginal communities and also distinguishing between them. The sisters were focused on the work within their own quadrangular cloister, and the wall surrounding St Joseph's spoke strongly of confinement, but the township itself and particularly the cottages set their lives in a landscape that was not simply institutional.

7 'Chronicle of the Benedictine Community of New Norcia' (hereafter Chronicle), NNA, 20 February 1916. 


\section{Dormitories}

Mission dormitories have become synonymous with the destruction of culture as institutional structures replaced other traditions. At New Norcia the surrounding 'village' of Aboriginal families, whose children lived in the 'Girls' House' or the 'Boys' House' but still had contact with their parents and networks, kept the cultural negotiation constantly in focus. But in the early twentieth century the improvement of dormitory facilities outweighed attention to housing for family groups. (Olivey thought these were 'good substantial huts ... but very uncared for [in] appearance'. $\left.{ }^{8}\right)$ The common sleeping arrangements emphasised a shared life, with missionaries and the girls in close proximity. As Torres reported in 1911, the then newly completed dormitory measured 127 feet by 23 feet (or $39 \mathrm{~m} \mathrm{x} 7 \mathrm{~m}$ ). ${ }^{9}$ There were two sections, both 'spotlessly clean and neat', with 14 beds in one and 15 in the other. Abbot Torres may have built with the future of the oblate community in mind, as the structure included eight small rooms for potential sisters (two at each end of each dormitory). Both dormitories also had common wardrobes: two small rooms, one at each end, for storing clothes, and there was more storage for boots and shoes, 'left by former inmates [and] repaired', ${ }^{10}$ in the cellar below. The bulk storage of shoes and clothes, even more than eating and sleeping in large groups, marked the life definitively as communal.

According to the carefully lettered timetable for St Joseph's at the back of Olivey's report, the dormitories were the space where most time was spent: the girls went to bed at eight o'clock in the evening and began the day after nine and a half hours rest, at five thirty in the morning. Improbable as this pattern feels to us, it would have mirrored the daylight through most of the year and the monastic routine of the sisters. Like the rest of New Norcia, St Joseph's was lit by kerosene lamps at this time, and the town took its cue from the routine of the monks. Even in the 1960s the monks' office of Compline ended the day and the local generators were closed down religiously at nine o'clock. ${ }^{11}$

8 Olivey, Report, 1913.

9 Torres to Chief Protector, 'New Norcia Mission: Annual Report 12 months ended 30 June 1911', SROWA S1644 cons652 1911/1475.

10 Olivey, Report, 1913.

11 Sr Leonie Mayne RSJ, Telephone Interview, May 1999. 
Each dormitory also had a 'lavatory' attached, facing the central square. There were three separate bathrooms near the enclosing wall, and each girl was 'compelled to take a bath ... every Saturday'. ${ }^{12}$ Adjoining these, Olivey reported a fowl house, pig-pen, dovecote and apiary, 'all attended by the children'. ${ }^{13}$ Of these, the chickens and the sought-after freedoms of being a 'fowl-yard girl' are an especially strong tradition. The pigs, pigeons and bees are hardly remembered, but the general layout, with animals near the bathroom, mirrored many peasant farmhouses in Spain and Ireland.

The dormitories themselves broke down the village assumptions and enabled stronger and more constant oversight by the mission as an alternative to family life. Convinced that their influence would always run second to the impact of families and friends, the sisters 'deplore[d] ... losing girls who were doing well'. ${ }^{14}$ In words that ring with irony and pain for many Aboriginal families, they lobbied for increased protection against 'anyone taking them away'. ${ }^{15}$ It was only 'orphans or others with no parents or friends in the vicinity ${ }^{16}$ who were likely to stay until they married, as the mission hoped:

His Lordship Bishop Torres told me it is very hard to do much good for some of the children who attended the school as their parents come and remove them, often when they are just beginning to improve, those coming from afar have the best chance. ... The Bishop would like to get absolute control of the children put under his care for some years, up to the age of 14 or 16 , then he felt certain good results would follow. ${ }^{17}$

The hope was for 'absolute control'. The lament was that it was being resisted. The question was: who would arbitrate the meaning of 'good results'? For Olivey on his tour, the smooth running of the institution counted for a great deal; for the sisters and the girls, the routines he applauded depended on a commitment to shared and regular work, especially in the laundry but also in the kitchen.

12 Olivey, Report, 1913.

13 Olivey, Report, 1913.

14 Olivey, Report, 1913.

15 Olivey, Report, 1913.

16 Torres to Chief Protector, 'New Norcia Mission. Annual Report for Year ending 30 June 1913', SROWA S1644 cons652 1913/1273.

17 Olivey, Report, 1913. 


\section{Laundry and clothing}

Across the square from the dormitories, there was the open side of the laundry, renewed in 1910 with running water, wash troughs and a builtin copper. We have seen how the laundry and washing day in particular could be a flash point for conflict. The records take the efficient running of the enterprise for granted in these years, however, probably in silent testament to good teamwork between the sisters and the young women at St Joseph's.

The hard work of washing efficiently for their own household, for some of the 26 families in cottages, as well as for the 'Boys' House', the 33 resident lay brother-labourers, and 18 other monks ${ }^{18}$ relied on coordinated physical labour. It was no small task to tend the large coppers of boiling water, beat and lift the load with wooden sticks and paddles, scrub the dirty clothes with soap on the washboards, treat various stains, work the mangles, manage the 'blue' bleach and the starch, hang out the wet loads and bring in the dry. The household used some six cases of soap, worth $£ 58$ s in a typical year. ${ }^{19}$ The clotheslines stretched across the courtyard of the new St Joseph's buildings and defined the space.

Washing day on Monday was followed by ironing on Tuesday. In all weather, especially in the West Australian summer, this also was tiring work, involving underrated skills. Sister Maria, and the unspecified number of 'older girls', used flat irons heated on wood stoves to press the clothes, learning by experience when the irons were hot enough but not too hot and how to keep the heavy metal clean so that ash or caught starch would not mark the clothes.

Once washed and dried, clothes also required mending; this was Wednesday's task. There was a storeroom for clothes and linen alongside the laundry. ${ }^{20}$ When Fr Edmund McCormick gave evidence on behalf of New Norcia at

18 Torres, 'New Norcia Mission - Annual Report for 1908', SROWA S1644 cons652 1909/0171; 'New Norcia Mission. Annual Report for Year ending 30 June 1913', SROWA S1644 cons652 1913/1273. Fr McCormick's evidence to the 1905 Roth Royal Commission gave the number of girls in the school as 39, the number of cottages as 26, and noted 39 lay brothers with six at outstations ('The Aborigines Question: Evidence Taken by Dr Roth', Western Mail, 20 February 1905, 19-20). The monastic community numbered 51 in total, P. Hocking, 'Benedictine Community 1900-1905', NNA 05517.

19 Torres, New Norcia's Annual Report to Chief Protector Prinsep, 10 September 1906, NNA $05132 / 96$.

20 Olivey, Report, 1913. 
the Roth Royal Commission in 1905 he highlighted 'a considerable amount of mending for the community' over 'their own cooking and washing under the superintendence of the sisters' and 'light' work gathering olives and helping to make the olive oil. ${ }^{21}$ In the same year, the monastery purchased 40 yards (or about 36 metres) of material for dresses at 8 pence a yard, and spent $£ 15$ on 'underclothing, aprons and hoods'. Seventy pairs of shoes cost $£ 2410$ s and repairs to shoes, no doubt by the monastery's bootmaker, were priced at $£ 14 .{ }^{22}$ Inspector Olivey called on a Wednesday and saw how 'the elder girls make all their own clothes and do all the mending and repairing'. The sewing reached a high standard. ${ }^{23}$

St Joseph's had a well-established reputation for embroidered fancy work. In 1908 Lady Bedford visited with her husband, the governor of Western Australia, and was given 'some choice specimens of ... work', presumably embroidery, by the sisters and 'one of the native girls. ${ }^{24}$ By 1914 it was the abbot's view that 'every year [they] gain prizes and certificates of merit at the local annual exhibition for their needlework'. ${ }^{25}$ Travel either by coach or on foot for the 10 miles to the Yarawindah Hall to see the exhibits at the Victoria Plains Show had become a tradition. ${ }^{26}$ The sewing in particular was a sign to the inspector of the careful training the girls were receiving. For the abbot, their practical domestic skills were 'so as to put them in a position to become useful in their future life, ${ }^{27}$ equivalent to trade training and farm work for the boys. Perhaps the training bore fruit. At the start of the school year in 1913 Sr Ita from St Gertrude's wrote to Abbot Torres needing help with the separate laundry work there, hoping for 'some arrangement as to getting the native women to help us'. ${ }^{28}$ If the girls who had refused to wash in the stand-off of 1908 were still in town they might have found something more like employment to fit their skills. Perhaps or perhaps not. The written records do not tell us, but later generations of Aboriginal women were paid for work at the colleges. ${ }^{29}$

21 'The Aborigines Question', Western Mail, 20 February 1905, 19-20.

22 Torres to Prinsep, 10 September 1906.

23 Olivey, Report, 1913.

24 Western Mail, 14 November 1908, 33.

25 Torres, 'New Norcia Mission. Annual Report for Year ending 30 June 1913', SROWA S1644 cons652 1913/1273. See also Chronicle, 12 September 1906.

26 Chronicle, 15 September 1909, 28 August 1907. See also Western Mail, 12 October 1907, 9.

27 New Norcia Mission Annual Report, 1911, SROWA S1644 cons652 1911/1475.

28 Sr Ita to Torres, 26 February 1913. Archives of the Sisters of St Joseph of the Sacred Heart, South Perth.

29 Veronica Willaway, Interview, Nebraska, June 2014. 
Alongside the new laundry, the kitchen at St Joseph's had been renovated. ${ }^{30}$ It was another site of practical training and opens out consideration of essential domestic work one step further.

\section{Kitchen and food}

Cooking was labour intensive. Olivey noted the cooperative work: 'two half-caste girls were doing the cooking under the supervision of a Sister'. Observing the work in progress, he found that the kitchen and dining room were 'perfectly clean and in order'. ${ }^{31}$ Large cast-iron pots, pans and ladles testify to slow-cooking in bulk on the wood-fired stove, and occasional lists of supplies compiled for accounting purposes take us closer to the food that might have been on the table. Abbot Torres advised the Chief Protector Henry Prinsep of the cost and amount of food supplied 'for the native children of the colleges' in $1905 .{ }^{32}$ Between the beginning of July 1914 and the end of June 1915, someone at the monastery was keeping a record of the meat, bread, milk and other produce supplied to all four of the schools across the road and making rough calculations about the value of what was provided or bought.

The lists are anything but a menu, but they suggest a diet in which meat and bread were staples, along with flour, sugar, rice, macaroni and tea. We know that in 1914 and 1915 this was supplemented by fruit, especially when the grapes and oranges were in season, milk (although none was supplied in March or April 1915), some vegetables, and other 'sundries', like the 140 pounds $(64 \mathrm{~kg}$ ) of garbanzo beans (or chickpeas) scratched at the bottom of the page as an afterthought and costing 12 shillings. ${ }^{33}$ It seems that the community of about 30 at St Joseph's used an average of 278 pounds $(126 \mathrm{~kg})$ of meat each month. This averages out at nearly 2 pounds 10 ounces $(1.2 \mathrm{~kg})$ per person per week, with higher provision in winter than summer. ${ }^{34}$ Bread from the bakery ran to 2,392 loaves for the period, or about two loaves each week for each St Joseph's resident. If the figures for St Gertrude's are averaged to take account of the lull in their kitchen during the school holidays, meals there involved comparably more meat each week, about 3 pounds $(1.3 \mathrm{~kg})$ per person, with half as

30 Chronicle, 3 April 1908.

31 Olivey, Report, 1913.

32 Torres to Prinsep, 10 September 1906.

33 Cashbook, 1914-1915, NNA 2969A/48, 86-93.

34 A total of $4 \mathrm{lb} 6 \mathrm{oz}(1.8 \mathrm{~kg})$ per person each week in the winter of 1914 compared to just over $1 \mathrm{lb}$ a week, or about $60 \mathrm{~g}$ each, in the summer of 1915. 
much bread. At the same time, the boys at St Mary's were eating more: each resident there accounted for something over 5 pounds $(2.5 \mathrm{~kg})$ of meat a week and a loaf and a bit of bread. Only bread and meat were allocated separately to the Aboriginal boys, but we know their meals were carried across town from St Joseph's kitchen, so it is possible that both institutions shared St Joseph's other stores: the 4 gallons (15 litres) of milk each week, the 10 dozen oranges for the season, some five dozen lemons, and the 304 pounds $(138 \mathrm{~kg})$ of grapes. There was also vinegar, olive oil, wine, $£ 11$ s worth of macaroni, 'fowls' to the value of $£ 31 \mathrm{~s}$ and a turkey in May 1915. It is likely that St Joseph's own hens supplied eggs and perhaps other birds for the table. Certainly the fowl-yard girls in later generations trapped and tended wild ducks and pigeons. ${ }^{35}$ Of the kitchens being supplied, it was only St Joseph's that drew an allocation of sheep's heads and livers, at an average of 15 of each, every week, and a record 81 for the month of January 1915. Consumption of other meat was at its lowest in this month. As it was summer perhaps the sisters used the offal to make brawn, but soup was a staple and more likely.

Sheep's head soup was a mainstay at St Joseph's through the years when the monastery did its own butchering, until the early 1960s. It features in oral accounts of St Joseph's as both a horror memory and a focus for cheerfully macabre stories of 'fighting for the eyes'. ${ }^{36}$ Whether Maria Harispe drew on recipes from her home country of Paraguay where eyes of various animals were used in tapas, or whether the broth at St Joseph's followed the directions from classic British cookbooks that added 'forcemeat balls' of the tongue and brains baked in breadcrumbs as something like croutons,${ }^{37}$ the experience stayed with the Aboriginal girls as distinctive of their childhoods.

The Golden Wattle Cookbook, icon of housewifery in Western Australia through the twentieth century, set its sheep's head soup recipe between one for scotch broth and one for tomato soup. ${ }^{38}$ It gave directions for cleaning the head and included carrots, turnips, onions and celery once the broth had simmered. In this version brains and tongue prepared with sage were chopped and served separately with a white sauce. From fresh ingredients to dishing up took somewhere between six and nine hours, depending on

\footnotetext{
35 Georgina and Mae Taylor, Interview, New Norcia, May 2017.

36 Mae Taylor, Interview, New Norcia, October 2001.

37 Mary Harrison, The Skillful Cook: A Practical Manual of Modern Experience (London: J. M. Dent and Sons, 1906), 85.

38 Golden Wattle Cookery Book, compiled by Margaret A. Wylie (Perth: E. S. Wigg and Son, 1924), 30.
} 
how long the bones were simmered so as to soften. The whole thing turns stomachs in cultures that have lost the traditions of using the whole animal, but powsowdie, the Scottish sheep's head broth, and other similar dishes are enjoying a slow-food revival on gourmet and ecological grounds. ${ }^{39}$ Such meals were promoted in British cookbooks at the turn of the century, especially during the First World War. ${ }^{40}$ In these years the dish was a staple through the British Empire, including for breakfast.

For the other end of the day, and for celebrations, the Teresians had had a reputation for skilful baking. Whether the fine sponge cakes and reposteria sweets that so impressed the judges at the local show continued and whether the monks still received feast-day tubs of rich dessert crema is not certain. ${ }^{41}$ We are sure, though, that Teresa Roca made the rich Spanish nougat, turrón, as a Christmas treat into the 1930s and probably beyond. (There was consternation when the new community at Drysdale River took the almond grinder with them for the same purpose and New Norcia's had to be replaced..$^{42}$ ) As lay sisters, Maria and Teresa inherited the traditions of home-made confectionery that had supported friendship networks and income for Spanish convents since the sixteenth century. ${ }^{43}$

Cooking was not only fundamental in the daily routine of the town but also part of the domestic training featured at St Joseph's. One newspaper account in 1910 had noted the 'useful branches of civilised home-life' that the mysterious sisters, 'black-robed nuns', were teaching with 'exemplary patience' to pupils who seemed 'an exceptionally intelligent lot'. ${ }^{44}$ That the girls' intelligence was directed to domestic training fitted with Salvado's principle of education for practical purposes, not roles that would be out of reach in a racist context, but there also was a classroom set aside for formal lessons.

39 See, for example, British Food in America, www.britishfoodinamerica.com/The-Hardship-WarAusterity-Number-Part-2/the-lyrical/An-Appreciation-of-the-sheep-s-head-both-at-the-table-andon-the-page/\#.X3QPeVllNTY; accessed 24 March 2014.

40 Nicola Humble, 'Little Swans with Luxette and Loved Boy Pudding: Changing Fashions in Cookery Books', Women: A Cultural Review 13 (2000): 322-38.

41 For affirmation of the Teresians' nougat, see Chronicle, 18 June 1905, 25 December 1906, 31 March 1907; for dessert cream, 14 July 1907.

42 Catalan to Benedictine Missionary Sisters at Drysdale River, 9 January 1933, NNA 01434 f.17.

43 Rachel Laudan, 'Convent Sweets', in Oxford Companion to Sugar and Sweets, ed. Darra Goldstein (Oxford: Oxford University Press, 2015); Eddy Stols, 'The Expansion of the Sugar Market in Western Europe', in Tropical Babylons: Sugar and the Making of the Atlantic World, 1450-1680, ed. Stuart B. Schwartz (Chapel Hill: University of North Carolina Press, 2011), 242-43.

44 James Thompson, 'Three Thousand Mile Trip', Western Mail, 5 November 1910, 44, 23. 


\section{Classroom}

Five years after Torres abandoned hopes for the colegia de nativas, there were few signs of academic ambition at St Joseph's and no institutional memory of the hope for integrated education at St Gertrude's, but educational success was still measured in traditional European terms. In the single 'airy and well-ventilated' room on the south side of the quadrangle, Inspector Olivey reported some girls wrote, others sewed, while 'a few of the youngest [were] learning to keep quiet'. ${ }^{45}$ The school program meant that 'most of them read and write fairly well ... and they could count a little, but that is about all'. ${ }^{6}$ The sister in charge, more likely to have been Elias than Consuelo, in conversation with the English-speaking inspector told him that she had little success in teaching geography or mathematics, but the report affirmed the children's 'intelligent interest in their work and play' and found they 'seemed perfectly happy and contented'. ${ }^{47}$

Whether we take the assessment of institutional happiness at face value or not, there were tensions between the mission and the children's families, with schooling as the touchstone. In these years, the conflict was not because children were being compelled to remain but because New Norcia did not have the power to overrule their parents. In the month following Olivey's visit, Abbot Torres urged the department to impose the requirements of the Elementary Education Act for compulsory schooling 'until 14 or 16', arguing 'it would not be doing any violence to Native parents to oblige them to send their boys and girls here to be trained and educated'. ${ }^{48}$ Torres, who was apparently unaware of the Act's provisions to exclude Aboriginal children from state schools, ${ }^{49}$ had also not modified his approach since the wholesale rejection of combined classes at St Gertrude's. If 'parents of our white children even at the furtherest end of the state don't look upon this [schooling at New Norcia] as any sacrifice', ${ }^{50}$ why should Aboriginal families object? The Benedictine sisters did not propose a solution but 'admitted feeling much discouragement ${ }^{51}$ because promising pupils left.

45 Olivey, Report, 1913.

46 Olivey, Report, 1913.

47 Olivey, Report, 1913.

48 Torres, Annual Report to the Chief Protector, 1913.

49 Anna Haebich, For Their Own Good: Aborigines and Government in the South West of Western Australia 1900-1940 (Nedlands, WA: University of Western Australia Press for the Charles and Joy Staples South West Region Publications Fund, 1992), 88-9, 133, 166-68.

50 Torres, Annual Report to the Chief Protector, 1913.

51 Olivey, Report, 1913. 
As evidence of the work being done, the inspector attached samples of writing from five of the children, from 7 to 11 years old. Across town at the boys' school directed by Br Luis Arrufat the sense of disconnection between the school and its context is strong, even absurd. Nine-year-old Patrick Yapo Williams was working from a Philips'Semi-Upright Copybook on phrases concerning 'the four great bulwarks of English liberty' and the impact of the 'Great and Glorious Revolution'; Charles Sandstone's copybook showed a fine hand after two years at school. Placid Farrell's 'Story of Some Hot Water', featuring the Irish Marquis of Worcester in prison, was 'the most advanced'. At St Joseph's the focus was closer to home. Olivey filed work by Mary Stack, Louisa Ingram and Christine Picket, who had each written out the Lord's Prayer from memory and completed a dictation test. We can hope the gauche tribute to the sisters signals that it was worded by the inspector:

Yesterday we went to the bush, and had a very nice time. Sister said she would take us again next week if we are good children. We will try our best and please the kind Sisters who are so good to us. They wish us to be not only good and obedient, but also clever. Friday will be our day for the bush. ${ }^{52}$

Two of the three writers capitalised 'Bush', hinting at the significance of this tradition of days out of town that dated back to Salvado and connected to life before the mission. Spelling 'obedient' was a challenge, but the virtue was taken more for granted in this system than the underlined quality of being 'clever'.

Transmitting a clear sense of Catholic values had been a priority outranking simple 'cleverness' since the time of Salvado. While shared values meant more than doctrine and a knowledge of Catholic observance, there was a sense in which the church at the centre of town was also an extension of the classroom. The daily routine copied carefully at the end of Olivey's report specified morning prayer and Mass at six o'clock in the morning, and evening prayer at six-thirty at night. Twice a week in the evenings from December 1906 there was a short sermon in the church in English, something of an innovation in the Spanish mission where most prayer was in Latin. The adult workers from the cottages were expected to attend this

52 Olivey, Report, 1913, appended, original emphasis. 
weekday session, as well as Sunday Mass. ${ }^{53}$ In 1913, the girls impressed Olivey with their 'devout attention' and the 'careful training' behind their capacity to sing hymns and part-songs and to recite well..$^{54}$

The Benedictine focus on liturgical prayer meant music and singing was not a refinement so much as a practical skill for the life of the wider community. Expertise in domestic work counted for a lot in the regime at St Joseph's, as we have seen, but music also held a place in the timetable. New Norcia's tradition of congregational singing was flourishing, and the girls' choir as well as the boys' continued to give the liturgical responses. Both practices put New Norcia ahead of the changes that would come 50 years later at the Second Vatican Council. ${ }^{55}$

Music and ritual bridged the secular and sacred. The monastery recorded events that stood out of the normal liturgical round, from the stark vigils of prayer before major feasts ${ }^{56}$ to the crashing noise at the end of Good Friday's tenebrae. This loud fragor was meant to evoke the earthquake of Christ's Passion for the monks, but the Chronicle admitted it was simply the 'best part of the entire Office for the children'. ${ }^{57}$ Celebrations with a liturgical edge also included a 'vigil' held by a bonfire on the eve of Holy Trinity and the dancing which followed, probably led by Aboriginal musician Paul Piramino. ${ }^{58}$ Visitors had long been impressed by the 'relish and artistry ${ }^{59}$ of the Aboriginal dances at New Norcia and joined in alongside women from neighbouring farms, so that 'they were dancing one European with one Aborigine'. ${ }^{60}$ New Norcia's tradition of modesty set limits. When the girls were keen to 'match steps with the boys ... the Sisters told them to pull back, as was fitting. ${ }^{61}$ Folk dancing could cross the racial line but it was only safe when it was single-sex. The gendered division of the town was second nature in a monastic environment, and increasingly New Norcia's authorities were concerned to maintain the boundary of the mission itself.

53 Chronicle, 7 December 1906.

54 Olivey, Report, 1913.

55 Eladio Ros, 'Music at New Norcia: A Historical Survey, First Period', unpublished manuscript, NNA S13.A3.4, 40.

56 Chronicle, 20 April 1905, 28 March 1907, 30 May 1907.

57 Chronicle, 27 March 1907.

58 For more on Paul Piramino, see Ros, 'Music at New Norcia', 67; Anna Haebich, Dancing in Shadows: Histories of Nyungar Performance (Crawley, WA: UWA Publishing, 2018), 123, 144-70.

59 Santos Salvado to Sr Gertrude, Compostella, describing a dance in 1878, cited in Ros, 'Music at New Norcia', 41.

60 Chronicle, 25 May 1907.

61 Chronicle, 25 May 1907. 
This concern with the limits of influence pervades the monastery's reports in this decade. Alongside confidence in the work at St Joseph's, an anxiety that the mission would be undermined by influences outside its control was a steady theme. In the months after Olivey's visit in 1913 the abbot summarised that St Joseph's was 'happy and successful', the girls were hard-working, beautifully behaved, in good health and 'well worthy of their faithful teachers'. He maintained that 'they are not treated as orphans but more like the children of "the well-to-do". ${ }^{62}$ And in that clanging phrase there is the rub.

The abbot and the sisters were increasingly conscious that the wider Aboriginal community was not 'well-to-do'. While they certainly knew some girls had families in town and elsewhere, they were keen to protect all the residents from influences beyond the mission. Abbot Torres wrote tellingly of 'our Natives' and the hope for segregation:

On the whole we are very satisfied with the work we have done for our Native charges during the past year and we hope it may be productive of future good for all concerned, but we fear much of this good may be jeopardised when 'our Natives' hereafter get mixed up with their fellows outside of whom no care whatsoever is taken, and we regret many of these are growing up in the vicinity of New Norcia. ${ }^{63}$

The question of the limits of the mission underpins one case on the public record in which Consuelo played a key role as director at St Joseph's. It shows us the dynamics around St Joseph's as a site and the web of subtle and not so subtle assumptions in play as Consuelo interacted with an Aboriginal family.

In mid-January 1917 Sister Consuelo wrote to the state's Chief Protector of Aborigines to put the case of an Aboriginal woman; she is named in the record, but let us call her ' J.' ${ }^{64}$ It was rare for anyone at New Norcia except the abbot or his deputy to write to the government, but Consuelo initiated this exchange. She chose to write to the government instead of consulting the monks, and she named herself superintendent of the institution. Heavily pregnant, J. had arrived at the mission sometime around

62 Torres, Annual Report to Chief Protector, 1913.

63 Torres, Annual Report to Chief Protector, 1913.

64 Consuelo to Office of the Chief Protector, 14 January 1917, 'Sr Consuelo. New Norcia. Reporting That Native Woman Recently Living with Indian John Michael Is in a Destitute Condition', SROWA S1644 cons652 1917/0331. 
Christmas with her common-law husband, M., and their five-year-old daughter, D. According to the mission, they asked to place their daughter at St Joseph's but, after a few days, 'as the youngster was continually crying, the sister [Consuelo] advised the father to take her back'. ${ }^{65} \mathrm{M}$. did this, but then he left New Norcia almost immediately, leaving D. with her mother in one of the cottages without food or clothing, ${ }^{66}$ so that both came each day to St Joseph's for provisions. ${ }^{67}$ The little girl would have been welcome to live in, and the abbot assumed she was already there, but when J. 'begged to be admitted also into the Orphanage', ${ }^{68}$ she was refused because her pregnancy was, as the abbot put it later, 'not adifying [sic] to the larger girls'. ${ }^{69}$ Consuelo arranged that another Aboriginal woman in another cottage would take them in, while the mission provided food and clothes. ${ }^{70}$ Significantly for our understanding of the site, Consuelo enforced a boundary between St Joseph's and the cottages: first in response to D.'s crying distress, and then, more resolutely, to uphold a moral code against unmarried pregnancy.

Some two weeks passed with the mother and daughter in a cottage at New Norcia and the father somewhere else unspecified. Then, acting on J.'s request, Consuelo asked the Chief Protector for a train ticket to Guildford so that J. could go to the 'old women's shelter ${ }^{71}$ to give birth. Either informed by J. or drawing her own conclusions because, as she told the Chief Protector, 'his own wife is still living, ${ }^{72}$ Consuelo assumed the man was not coming back. Consuelo put the case starkly to the Chief Protector:

She is in a most destitute state: no one in the cottages around will give her shelter. We await your answer to see what can be done for her. ${ }^{73}$

The Chief Protector's office checked their files of 'personal particulars' but could find no information. They decided a ticket to Perth would be more appropriate and sent one, asking Consuelo to fill in the appropriate names.

65 Catalan to Chief Protector, 8 February 1917, NNA 01418/131.

66 Catalan to Chief Protector, 8 February 1917.

67 Consuelo to Office of the Chief Protector, 14 January 1917.

68 Catalan to Chief Protector, 8 February 1917.

69 Catalan to Chief Protector, 8 February 1917.

70 Catalan to Chief Protector, 8 February 1917.

71 Consuelo to Office of the Chief Protector, 14 January 1917.

72 Consuelo to Office of the Chief Protector, 14 January 1917.

73 Consuelo to Office of the Chief Protector, 14 January 1917. 


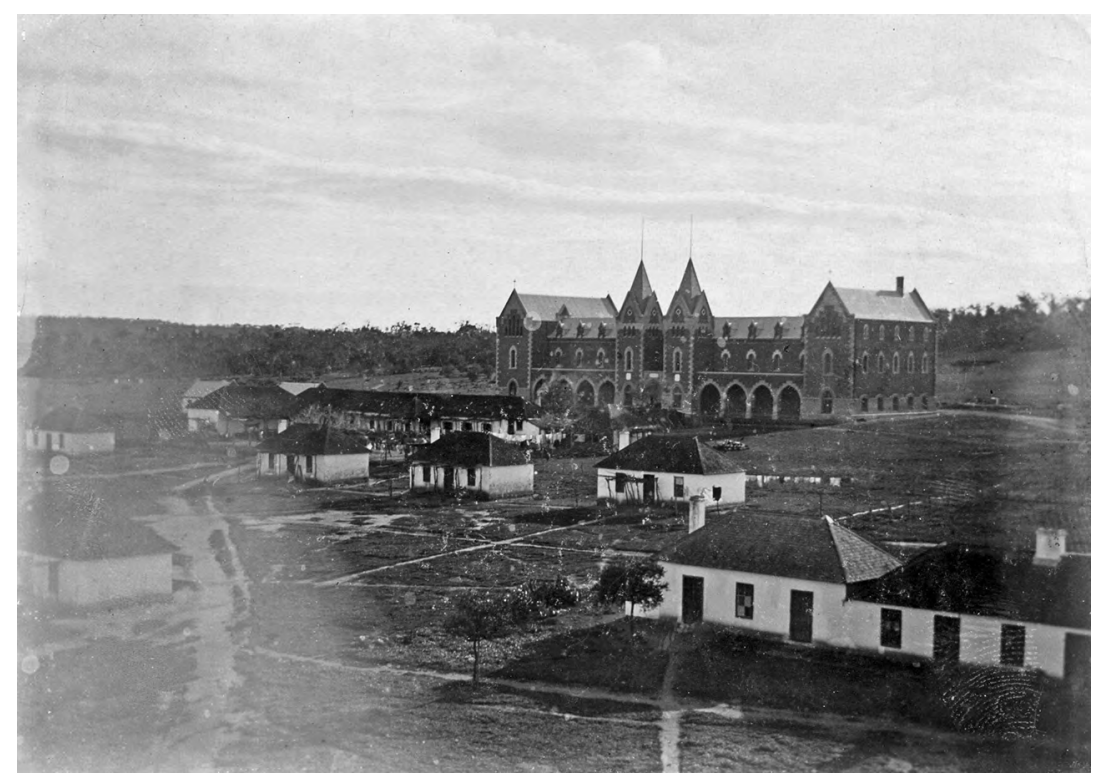

Figure 4.5: Cottages for Aboriginal workers and families in front of St Gertrude's College; St Joseph's rear left.

Source: NNA 74433P.

If the story ended here, we would see Consuelo had intervened on behalf of J., perhaps to some good effect. But at the same time, J. received a letter from M. enclosing money for a fare to Guildford. Consuelo's advice was to travel on through Guildford to Perth. Perhaps she was being obedient to the Chief Protector, perhaps she was unpersuaded that a de facto relationship could be stable, perhaps she did not think $M$. would be there at all; J. disagreed and insisted she would go to join M. in Guildford. As the abbot reported it later, J. 'became insolent and abusive ${ }^{374}$ towards Consuelo. We do not know, however, whether this was before or after Consuelo took the decision that five-year-old D. would not travel with her mother.

It is not clear what form the confrontation took, or whether it happened at New Norcia or at the Mogumber station, but on the file copy of Consuelo's telegram advising the Chief Protector to 'please meet Aboriginal woman [J.] going train to Perth', there is a departmental note that 'arrangements have been made to stop the train at Guildford'. ${ }^{75}$ Someone, perhaps in 
the face of J.'s distraught insistence, overruled Consuelo on the matter of destination. This was on a Friday. An undated letter from M. to the Chief Protector, written within the week, protests that his wife is 'too much upset' and 'worrying and fretting night and day for her child'. ${ }^{76}$ The following Friday, 2 February 1917, the Chief Protector wrote to Abbot Catalan, restating J.'s anxiety and the parents' hope to have D. sent to Guildford. He asked with bureaucratic flourish to hear 'the reasons which actuated you in retaining the child'. ${ }^{77}$ The abbot replied with the details of the initial involvement of the mission, reiterating the parents were not married, noting that $\mathrm{D}$. and her parents were all Catholics, by which he may have meant that the mission had some authority to judge in this matter. He reported that J. 'willingly left the child at the Orphanage' and that D., 'now accustomed to the other little ones', was 'still very happy' there. ${ }^{78}$ The Chief Protector sent the police to ask M. to call in again and wrote to the abbot again on 20 February, advising that both parents 'appear to be emphatic in their desire to have the child returned to them'. The new baby had arrived, a son, and 'J. appears to be well able to look after the little girl'. ${ }^{79}$ On Monday, 26 February, word was sent to M. that the abbot was sending his daughter, and on Thursday, 1 March 1917, her parents met D. from the morning train at Guildford. The Chief Protector wrote to thank the abbot.

In this one instance of church and state implementing provisions for the 'protection' of Aboriginal Australians, the determined struggle of the Aboriginal parents to keep their daughter is compelling. The role of the sisters and their institution is also striking. Turning the pages of the file, St Joseph's fills multiple roles: networked with the cottages, while answerable to both the government and the monastery; offering support, while also implementing racist and moralising policies. The conflict between Consuelo and J. also moved quickly to become a wider drama played on a masculine stage. As Consuelo overruled J. to keep the child at St Joseph's, so M. appealed to the Chief Protector, and the Chief Protector sought advice from the abbot and then overruled that advice on his own assessment of the situation. Perhaps as the situation played out Consuelo also began to advocate that the little girl should go to Guildford, but we do not hear her voice. Consuelo was in direct contact with J. before any other

76 'M' to Chief Protector, n.d. but probably 29 January 1917, SROWA S1644 cons652 1917/0331.

77 Chief Protector to Catalan, 2 February 1917, SROWA S1644 cons652 1917/0331.

78 Catalan to Chief Protector, 8 February 1917.

79 Chief Protector to Catalan, 20 February 1917, SROWA S1644 cons652 1917/0331. 
figure of authority and could marshal resources for her as well as disrupt plans. She did not hesitate to intervene with the authority of the mission, but ultimately she did not determine events. For the Chief Protector and for the abbot, her role was entirely ancillary to theirs and would not determine policy. As this case shows, St Joseph's might have looked like a distinct institution at the edge of town but it was not autonomous.

Through 1917, tension deepened around Consuelo's role. Two issues mingle in the records: questions about the extent of her authority at St Joseph's merge with hints that her approach to religious life was out of step with the abbot and the other sisters. In the end, her decision that there was no space for her in New Norcia adds another layer to this chapter's spatial reading of St Joseph's. It points to ongoing tension between a vision for vowed obedience in the women's community, on the one hand, and aspirations for independent missionary work, on the other.

\section{Consuelo and St Joseph's: No separate sphere}

Consuelo's life was apparently increasingly fraught as she sought to protect a sphere of influence in a context where her loyalty was mistrusted. The warm regard she had enjoyed 10 years earlier had apparently faded, and there was scant respect for the missionary role she claimed for herself. The conflict also reflected dynamics within the monastic community itself where opinion was running against Consuelo's long-time supporter Fr Roberto Bas, and where Abbot Catalan himself was coming to grips with his new authority. In the midst of change, New Norcia was a quagmire of strong emotion. Consuelo found the ground slipping under her feet.

In March 1917, just one week after she had been overruled in her tussle with the Chief Protector and five-year-old D. had left New Norcia, Consuelo appealed to have St Joseph's exempted from the normal structure of monastic authority. Abbot Catalan was setting out for Europe, accompanied by Fr Roberto, and had left his prior, Fr Luis Tubau, in charge. Consuelo clearly felt she could not work with the young monk Tubau and wrote to propose an alternative. The note, sent in some distress $^{80}$ to the abbot at the boat in Fremantle, shows her navigating 
awkward territory. She wanted permission to 'deal with Fr Castenares in everything that concerns the house and the girls with the exception of anything in which there is the intervention of the Chief Protector ${ }^{81}{ }^{81}$ She knew she risked confirming a reputation for being difficult and was at pains to reassure the abbot that the request was 'not made by one who has the intention of quarrelling with anyone'..$^{82}$ Rather, she framed her request to circumvent monastic authority in spiritual terms. Consuelo underscored her intention for $p a z y$ caridad and saw a divine test in the community's tensions: 'my resolutions are for peace and charity and to benefit greatly from this sacrifice that God asks in order to sanctify me'. ${ }^{83}$ We do not know whether Abbot Catalan replied.

Conflict continued through 1917, apparently focused on the assumption that Consuelo's work was under the direction of the abbot and at the disposal of the monastery. At issue was the abbot's expectation and direction that Consuelo would sew for the monks. Consuelo found this 'unacceptable' ${ }^{84}$ She specifically refused to make new scapulars for a group of junior monks who made their profession on 6 November 1917. On the day of the profession Consuelo wrote to the abbot revealing their unresolved dispute about her role and responsibilities. She had been trying to speak to him since his own letter had affronted her in midOctober, but now she resorted to putting pen to paper:

Although you have told me not to write I see I am obliged to do so, as it is three weeks since I indicated I needed to speak to you privately and you have not given me an audience.

I suppose you remember that on 26 September last, my state, obligations and tasks at the Mission were under discussion, and the matter was pending, and so you will understand my wish to have things arranged soon. On 14 October I received a letter from you with such categorical phrases that surprised me very much, since I had not committed myself to anything and consequently Fr do not expect to make any further habits. If you would like a further verbal explanation, I will provide it. ${ }^{85}$

81 Consuelo to Catalan, 8 March 1917.

82 Consuelo to Catalan, 8 March 1917.

83 Consuelo to Catalan, 8 March 1917, original emphasis.

84 Consuelo to Catalan, 6 November 1917, NNA 00918.

85 Consuelo to Catalan, 6 November 1917. 
Discussion did not resolve the matter. Four days later Consuelo wrote to advise the abbot that she would be leaving New Norcia; she reminded him of a financial contract agreed with Abbot Torres in 1912 that would come into effect. ${ }^{86}$ Her claim for payment as a worker exercised Abbot Catalan, but he was even more clear that Consuelo could not leave town dressed as a sister, wearing the habit 'that distinguishes the other Sisters from the rest of the ladies of the world'.$^{87} \mathrm{He}$ even apparently suggested that she should leave St Joseph's immediately and do the necessary dressmaking elsewhere, staying with Juan and Catalina Casellas. In the abbot's view, the household of the monastery's woodcarver was a better venue for secular dressmaking. But Consuelo assured him that plan would only draw more attention from the girls and that she could prepare discreetly enough at 'home', at St Joseph's. ${ }^{88}$

While Consuelo prepared to leave town, the abbot wrote to his lawyer about the monastery's financial obligations. Catalan later told the Apostolic Delegate that they found the record of her oblation, but they could not find a contract; none of the other sisters were contracted. ${ }^{89}$ Negotiations took on an air of intrigue. A week after announcing Consuelo was to leave and reporting the advice that she should be paid $£ 1$ a week, the Chronicle noted the abbot was setting out to Perth to seek further information. The writer exploded and marked his text with exaggerated dots of ink to lament the absence of real information:

And...Incombustible Reader! Here at this point...I am more convinced this 'chronicle' is full of nothing but nonsense and great trivialities. That someone comes, that another goes, that a frog fa[rts]. ${ }^{90}$

By the following day, the diarist had recovered and announced that 'the disgraced Miss Consuelo' had been sent away. He recorded the venomous wish that Fr Bas, outspoken and opinionated, would meet this same fate as 'his prodigy', this 'pious penitent'. ${ }^{11}$ But Fr Roberto remained, and it was in fact another 10 days before Consuelo left New Norcia.

86 Consuelo to Catalan, 10 November 1917, NNA 00918.

87 Catalan to Consuelo, 26 November 1917, NNA 01418/79.

88 Consuelo to Catalan, 10 November 1917.

89 Catalan to Cattaneo, 17 June 1921, NNA 01849.

90 Chronicle, 20 November 1917, original ellipses.

91 Chronicle, 21 November 1917. 
While the furious negotiations about financial reparation for Consuelo's work continued, Maria Harispe made a rare intervention in writing. In an undated letter, she assessed the situation for the abbot in terms that disparaged Consuelo. Her focus is the dressmaking, but the implication is that Consuelo is, as usual, outside monastic norms. Maria reported that Consuelo was making not two but four dresses, and various blouses, and was altering a habit and using two lengths of fabric that had been bought for the girls. Maria thought all of this was improper but predicted that Consuelo would explain it away: 'you know how smoothly she talks'. ${ }^{92}$ The letter suggests that opinion was united against Consuelo. Maria was frank about the relief she would feel when Consuelo was gone; her regret was only for what she saw as the loss of Consuelo's religious vocation:

It seems to me Father, that if she goes and leaves us in peace she does us a great favour. ... She is very content and I (although I want her to go, as it seems right to me) sometimes I am more sad than happy to think that after having left the world for so many years she is so content to return to it..$^{33}$

Consuelo herself did not see her departure as repudiating a vocation. In her farewell letter to Catalan she first made her claim for a full $£ 282$, not the $£ 250$ he had furnished, and then asserted her conscience:

I am sorry to have to take this step, but I am convinced that this is the will of God. Forgive me what has been lacking, and commend me well to God. ${ }^{94}$

Her motives are lost to us, and assessments of her are contested, but this could have been a declaration that God outranked the abbot and the expectations of the community.

Consuelo left New Norcia, but she did not return to Spain or Mexico. Instead, as Miss Batiz, she took a position as a 'sewing teacher' at Carrolup in the southwest of Western Australia, near Katanning, at a settlement run by the United Aborigines Mission. She applied for a certificate of naturalisation, declaring it was 'her intention to remain in Australia', ${ }^{95}$ with references from Richard Lanigan, Jeremiah Clune and Charles

92 Maria Harispe to Catalan, n.d. but November 1917, NNA 00918.

93 Maria Harispe to Catalan, n.d. but November 1917.

94 Consuelo to Catalan, 26 November 1917, NNA 00918.

95 M. C. [Consuelo] Batiz to Secretary of Home and Territories Department, 24 June 1918, National Archives of Australia, NAA A1, 1919/1216 37354 f.20. 
Davidson, all neighbours at New Norcia. This move to an evangelical Protestant mission station to work as a sewing teacher with Aboriginal people, rather than remain at New Norcia and sew at the abbot's direction for the monks, underlines Consuelo's conviction about the purpose of her return to Australia. Her sense of missionary identity that outweighed her original commitment to the Teresian sisters now enabled her to break her connection to New Norcia and probably to minimise, if not compromise, her commitment to Roman Catholicism.

Consuelo was still at Carrolup in 1921 when she reopened her claim for further funds from New Norcia through the Apostolic Delegate, the representative of the Vatican in Australia. ${ }^{96}$ She may have been prompted by rumours that Carrolup was to be closed. When that proved true and most of the people were moved to the Moore River Settlement, a mere 6 miles $(9.5 \mathrm{~km})$ from New Norcia, Consuelo's nerve failed. By January 1922 she was in Mexico City. The Apostolic Delegate passed on her new address to Abbot Catalan, urging him to defray her travelling expenses. ${ }^{97}$ The abbot wrote to Mary Consuelo Batiz the following day to close the matter, noting: 'already we have done more than charity requires' ${ }^{98}$ He wished her a prosperous New Year and 'goodbye'.

The community of Benedictine sisters probably never heard that Consuelo had been in touch with New Norcia. The tension of her time with them had eased, and attention had turned to the need for new members. In September 1918 Abbot Catalan wrote, at the suggestion of Teresa Roca, to one of her priest friends in Barcelona, to ask him to recommend other women, around 30 years old, 'who have a spirit of sacrifice and good will to live in the Orphanage with the native girls and work in this Mission for the Glory of God and the good of these poor souls'. ${ }^{99}$ They hoped for up to six responses.

It was the first of many recruiting letters that Abbot Catalan would send on behalf of the sisters through his long tenure in office, and it sounded the domestic note that would inform them all: 'once in this Mission

96 Apostolic Delegation to Batiz, Ref 607/21, 23 July 1921. Copy at NNA 01849.

97 Apostolic Delegation to Abbot Catalan, Ref 1102/21, 17 January 1922. Copy at NNA 01849.

98 Catalan to Consuelo, 23 January 1922, NNA 01424/12.

99 Catalan to Rd. Sr. D. Luis Brugado, 27 September 1918, NNA 01418-01421/473. 
[the sisters] will be considered like family'. ${ }^{100}$ The mission would provide 'all the necessities of life'. ${ }^{101}$ While Abbot Catalan was thinking in financial terms, the statement would prove to be true on other levels as well. As surely as any family, New Norcia would have the capacity to transform their lives, nurture their hopes, and break their hearts. 
This text is taken from A Bridge Between: Spanish Benedictine Missionary Women in Australia, by Katharine Massam, published 2020 by ANU Press, The Australian National University, Canberra, Australia. 